\title{
Colombia's Fractured History and Continued Challenges Following the Havana Accord
}

\author{
Rafael R. Ioris and Antonio A.R. Ioris
}

Keywords: Colombia, Peace Process, Havana Accord, Development Promotion, Social Justice

Introduction: Rescuing a Failed Peace

It was a momentous occasion when, on November 12, 2016, after a tortuous course of events, Colombian president Juan Manuel Santos optimistically proclaimed the reaching of a final accord that would put an end to the longest military conflict in modern history. The leader of this violence-ridden nation sought to assuage the stalemate created by the defeat of the government's position in the referendum held on October 2, that same year. The rejection of what had become known as the Havana Accord, signed between the Colombian government and the FARC (Fuerzas Armadas Revolucionarias de Colombia), that same month represented an unmistakable and serious warning that, though essential, formal peace negotiations were not all the country needed. The revised agreement produced in the wake of the defeat in the referendum was later endorsed by the Colombian National Congress and, this time around, despite some criticism from 'No' supporters (particularly from the former president Alvaro Uribe and his conservative allies), Santos did not risk putting the document through a second referendum where another defeat was possible. Despite the feeling of achievement and the optimism conveyed by Mr. Santos, it remains to be seen how this revised agreement will be implemented and whether it will sufficiently redress the recent history of this important Latin American nation. A reflection on these important matters is the focus of this briefing.

Colombia's Protracted Exclusionary History

To understand the recent and potentially transformative events in Colombia, a brief history of the country is needed. To be sure, like much of the rest of Latin America, Colombian historical trajectory has been defined by continued and sharp socio-economic contrasts and the succession of fast-paced developmental initiatives. These include the country's remarkable insertion into the global economy as an important primary commodity exporter starting at the end of the 19th century, as well as the limited though regionally significant fast-paced industrialization of the middle of the 20th century.

Though successful in reshaping the socio-economic composition of several key areas of the country, these developments have not been instrumental in ameliorating let alone addressing the severe inequality that remains as a defining feature of the Colombian society (similar to all the other South American countries). To be sure, notwithstanding the remarkable degree of economic growth in the middle of the $20^{\text {th }}$ century, this was largely derivative of a cross-sectional alliance between traditional landowning families and regional industrialists who worked to consolidate control of the decision-making process in traditional oligarchic forces. Although, industrial workers did, and still do their best to push the boundaries of the local and national spheres of economic and political power (Farnsworth-Avelar 2000; Ioris 2014; Palacio 1983, 2006).

Similarly, the Colombian experiment with pre-accorded peaceful transitions of power among the two main political parties (Liberal and Conservative), called National Front, which functioned between 1957 and 1974, provided formal democratic stability at the cost of political 
exclusion. In fact, through clientelistic party affiliations and restricted legislation, more autonomous and popular forms of mobilization were barred from participating in formal politics (Hartlyn 1988:183). Finally, at the turn of the century, important segments of Colombian society mobilized collectively, calling for a new constitution, which promised a new start for the country and was the basis for widespread high expectations. Alongside these legal reforms, negotiations between the Colombian government and revolutionary groups have also marked the recent history of the country.

\section{Plan Colombia and the Recurrent Militaristic Logic of Peace Building}

Starting in the late 1990s, a series of attempts to address the continued problem of a lowscale yet deeply destructive civil war were pursued. In 1999, President Pastrana (1998-2002) agreed to the contentious U.S.-financed and designed Plan Colombia, aimed at curbing drug flow (cocaine and heroin in particular) over the Mexican border. Plan Colombia reduced the cultivation of cocoa plants, but not cocaine processing (now estimated at around $70 \%$ of global production), while aggravating the humanitarian crisis. Forced internal displacement from areal fumigation of defoliants not only affected coca production areas, but also many peasant-held lands. Continuing such a militaristic logic, in 2004, Álvaro Uribe (2002-2010) launched the Patriotic Plan, also with the direct involvement of the United States, which aimed to displace guerrilla groups and occupy remote areas traditionally controlled by them. New legislation passed the following year promised reduced punishments for both paramilitary and guerrilla fighters should they renounce violence and return assets appropriated illegally. FARC's response at that point was an offensive organized to counteract military action and undermine the perception that security could improve unilateral actions on the part of the central government.

Consequently, in 2010, the former Secretary of Defense under Uribe, Juan Manuel Santos, the leader who in 2016 secured the peace agreement, was elected president (after the courts decided that Uribe could not run for a third term in office). In 2012, Santos announced that the government would engage in talks with the FARC in order to explore alternatives to end the long conflict, learning from past mistakes and from the frustrated attempts that tried to resolve the issues militarily. Thus, in a climate of heightened national and international expectation, Santos proclaimed in September 2016 the complete settling of the dispute between the government and the FARC and revealed the details of a comprehensive truth and reconciliation process. The agreement included the admissions of guilt and the requirement of community service for perpetrators of violence.

Assessing the Havana Accord

Although not a legal requirement, President Santos had promised to submit the Peace Accord to a public referendum in order to legitimize its targets and the mechanism of retributive justice. In fact, given the tumultuous and exclusionary history of the country, it was largely based on these idiosyncratic actions of President Santos that a path to a final peace agreement seemed to be achievable. Yet, to the surprise of the international community, on October 2, 2016, a divided Colombian society rejected (by 50.2\%) the first version of the Accord. The negative result produced from the ballot boxes did not trigger a reopening of the hostilities, but forced the parties involved to go back to the negotiation table. It was not clear what would happen if the 'No' 
prevailed, but both the government and the FARC had already achieved so much, that there was a strong willingness to try to secure the anticipated peace.

Yet to be successful, the Havana Accord needs to be examined in light of the painful history of this Andean nation. Endemic violence has been a persistent problem and one important face of Colombian society throughout much of its history, not restricted to one sector or geographic region (Hartlyn 1988; Lopez-Alves 2000; Sanchez Torres 2007). Moreover, the persistent social inequality and wealth concentration of the country require that the top-down modernization and industrialization of the country in the middle of the last century be redefined toward a more inclusive socio-economic, political, cultural, and environmental frame of reference. The different levels of government have to be reorganized so that formerly excluded social segments, not restricted to guerrilla groups, are fully included in the formal democratic system, including the decision-making process regarding allocation of public services and the demobilization and integration of conflict areas.

Though laudable for trying to move beyond an overly militaristic approach to the structural lines of the continued conflict in the country followed by his predecessors, Santos' actions were largely aimed at integrating heretofore economically marginal regions into the global markets. Particularly since today's Colombia's mainstream policies have become ever more aligned with those of free-trade agreements, such as the Trans-Pacific Partnership. This is path that, though potentially capable of providing economic growth, is also prone to sustain the sharp social cleavages of the Colombian society, should the history of the country be any guide (Richani 2001). As potential counterpoints, land reform and the creation of restrictions to foreign involvement in key economic activities such a mining and oil exploration were some of the main demands the negotiators from the FARC presented repeatedly to the government in order to suspend military activities. To be sure, the tentative acceptance of the Santos administration's land reform orchestrated by the FARC has been seen by the insurgents and wider society as one of the most promising aspects of the peace process (González Rodríguez 2016). Yet, national and international business groups expressed firm interest in the possibilities of oil and mineral exploration (as in the case of the Pacific coast and in the Colombian Amazon) offered by the peace accord (information from meetings held by the authors at the American and British embassies in Bogota in 2016).

Land Accessibility, the Quintessential Challenge

The issue of land accessibility is central to any effective reforms in a country ravaged by land-tenure related historical conflicts. Even when an assertive land reform program was sought, such as in the 1960s, little was done to curb countryside violence that, over the last 60 years has cost 220,000 deaths, mostly of poor rural residents. In fact, even though land titling was conducted in many parts of the country, it was implemented piecemeal and incompletely, blocked in most areas by politically powerful large landholders, creating widespread levels of insurgent activity (Albertus and Kaplan 2012). Though it was possible for some sectors to thrive during the civil war years, particularly those better connected to legal and illegal global markets, the fact remains that for the country to fully realize its potential, a more inclusive path of political reconciliation has to be promoted. In this sense, the current prospects of the negotiation may signal a potentially conclusive settlement, capable of reducing the humanitarian costs involved in this protracted civil war, as well as facilitating access to Colombian natural resources. Yet, for a durable and in fact transformative peace to be achieved, further challenges remain. 
In this sense, a final and lasting peace in Colombia requires ample changes in existing democratic institutions so that the rule of law can be expanded to the areas of historical conflicts. Substantial measures could include some form of mini constituent assembly able to involve and thus place responsibility of other political actors in the process. Similarly, the Santos administration should seek to make a much better case for the value of any type of transitional justice, including the political incorporation of former guerrillas, along with their monitored military demobilization. Similarly, effective and peaceful integration of FARC into the political arena has to be paved by concrete means to prevent another debacle like the Unión Patriótica [Patriotic Union] of the mid-1980s, when more than 3,000 former members of the guerrillas who had joined the political process were murdered with total impunity assured by, when not with direct involvement of, the state apparatus (Walch 2016).

\section{The Path Forward: Concluding Remarks}

The peace accord may create new opportunities for trade with China and access to areas that were once inaccessible due to guerrilla activity. However, from the perspective of social justice and democratic stability, these actions must be coupled with a firm rejection of the continued path of neo-liberal integration of the country into the recent wave of economic trends, especially as the hemisphere as whole faces the revived protectionism of the United States, as promised by the Trump administration. Though an experience embedded in long, painful national history, the construction of a lasting and transformative peace in Colombia has the potential to reveal courses of action for much-needed, meaningful political and economic changes in Latin America, as well as in many areas of the developing world.

In the short term, the Santos administration needs to prove capable of preventing the derailment of the commitments made by both sides in the Havana Accord, largely by steering the process away from the rising right-wing rhetoric of his predecessor. Much in the same way, the slowdown in the global demand for Colombia's exports in recent years poses added challenges to consolidating an effective path toward peace. Thus, in order to be effective and lasting, an agenda along more inclusive lines of national development needs to be pursued, especially by means of effective political and economic incorporation of the most traditionally excluded social segments, particularly in the countryside.

Moreover, the political system needs to prove its willingness to fully incorporate demobilized groups and a path of truth and reconciliation should be pursued by all relevant members of the Colombian society. As in the case of previous conflicts, a crucial measure will be the effective access to land and the ability to maintain agricultural production in new rural properties to be established through the peace process. This will be a very challenging experience, considering the pressures of an increasingly globalized economy, the rapid urbanization and the advance of intense commercial agribusiness in the country. Genuine peace in Colombia is still a story without a clear end in sight.

\section{References}

Albertus, M. and O. Kaplan. 2012, Land Reform as a Counterinsurgency Policy: Evidence from Colombia, Journal of Conflict Resolution 57, 198-231.

Farnsworth-Avelar, A. 2000, Dulcineia in the Factory: Myths, Morals, Men, and Women in Colombia's Industrial Experimentation, 1905-1960, Durham, NC: Duke University Press. 
González Rodríguez, H. 2016, ¿Reforma agraria integral? El Espectador, published on Dec. 22, 2016. Available at: http://www.elespectador.com/opinion/opinion/reforma-agraria-integralcolumna-671691

Hartlyn, J. 1988, The Politics of Coalition Rule in Colombia, Cambridge: Cambridge University Press.

Ioris, A.A.R. 2014, The Political Ecology of the State: The Basis and the Evolution of Environmental Statehood, London: Routledge.

Lopez-Alves, F. 2000, State Formation and Democracy in Latin America, 1810-1900, Durham, NC: Duke University Press.

Richani, N. 2001. The Political Economy of Colombia's Protracted Civil War and the Crisis of the War System, Journal of Conflict Studies 21, 2.

Palacio, M. 1983, El Café en Colombia (1830-1970): Una Historia Económica, Social y Política, Bogotá: Editorial Presencia \& FEDEDESAROLLO.

Palacio, M. 2006, Between Legitimacy and Violence: A History of Colombia, 1875-2002, Durham, NC: Duke University Press.

Sanchez Torres, F. 2007, Las Cuentas de la Violencia, Bogotá: Grupo Editorial Norma.

Hartlyn, J. 1988, The Politics of Coalition Rule in Colombia, Cambridge: Cambridge University Press.

Walch, C. 2016, Rethinking Ripeness Theory: Explaining Progress and Failure in Civil War Negotiations in the Philippines and Colombia, International Negotiation 21, 75-103. 